\title{
THE IMPACT OF INFORMATION TECHNOLOGY PRACTICES AND ORGANIZATIONAL LEARNING ON FIRM INNOVATION AND PERFORMANCE
}

\author{
Cemal ZEHIR \\ Emine YILMAZ \\ Harun VELIOĞLU \\ Gebze Institute of Technology, Turkey
}

\begin{abstract}
The aim of this study is to research the relationship between information technology (IT), organizational learning, firm innovation and firm performance. For this study we developed a research model which includes IT practices, internal benefits of IT, organizational learning, dynamic benefits of IT, firm innovation and performance. For this reason, the data was obtained from a sample of 87 people who work in 18 different sectors. Results from our regression analysis were separated for each variable, and we found that IT practices, the internal benefits of IT, organizational learning, dynamic benefits of IT and firm innovation have a statistically significant effect on firm performance. However, with multiple regression analysis we saw that these variables, except firm innovation, do not have a statistically significant effect on the firm performance. So, we discovered that the result of firm innovation has a moderating effect between IT practices, internal benefits of IT, organizational learning, dynamic benefits of IT and firm performance. If the IT practices, internal benefits of IT, organizational learning, and dynamic benefits of IT are positive, firm innovation and performance will also be positive.
\end{abstract}

Key Words: Firm performance, information technology, innovation, organizational learning.

\section{INTRODUCTION}

The fundamental question in the field of strategic management is how firms achieve and sustain competitive advantage (Teece et al., 1997). IT usage, organizational learning and firm innovation have a vital impact on firm performance, which is the most important determinant of competitive advantage. So, the main propose of this article is to investigate how firms maximize their performance and what are the main determinants of firm performance.

This research is especially focused on the reasons behind business performance. In this context, the purpose of this research is to discover the relationship between IT practices, organizational learning, firm innovation and firm performance in the comprehensive competitive environment. It is current practice for firms to rely on information technology, give priority to innovation and provide organizational learning to enhance firm performance.

\section{THEORETICAL BACKGROUND and HYPOTHESES}

In this study, we have tried to examine the relationship between firm performance, information technology, innovation and organizational learning. According to this aim, we researched the related literature and after developing a research model and hypotheses, we made numerous analyses.

\section{Information Technology}

Information is a concept that changes from topic to topic and could not be provided a consensus on its definition. Information could be defined as data that could be organized to create value to organization, grouped, modelled, activated (Özgener, 2003). The role of information systems has changed dramatically over the last three decades, from a passive automation 
or augmentation tool to a strategic, competitive device for transforming organizational structures. Today, business operations and information systems are so tightly integrated with each other that it would be almost impossible to improve business processes unless corresponding information systems effectively supported the change (Lee and Kim, 1996).

In numerous studies, the impact of IT is investigated as a whole. In our research we divided IT into three parts to obtain better understanding about the impact of IT on firm innovation and performance. These are IT practices, internal benefits of IT, and dynamic benefits of IT.

Information technology (IT) has become the most potent weapon for managers to formulate and implement business strategies. Without the support of information systems, most business strategies cannot be carried out. The real power of IT can be realized in an organization only when it is aligned properly to support the organization's core business strategies (Lee and Kim, 1996). WWW.Amazon.com is the Internet web page address of the currently largest virtual bookstore in the world. More than one million titles are available. None of these is on store, but can be searched for and ordered interactively by remote Internet users located as far away as Herrenberg, Germany. The Amazon Company made sure though to locate near Seattle, Washington, to have easy access to the largest physical book warehouses in the U.S. Their web site even offers an alert function, which automatically sends an electronic mail (e-mail), whenever a new book has been published; whose profile (author, title, subject, etc.) the customer is interested in. This Amazon selection and ordering process would not be possible without the Internet technology (Schumacher, 1997).

\section{H1: Information technology practices have direct and positive effect on firm innovation.}

During the past two decades, both business managers and academic researchers have shown considerable interest in understanding how information technologies (IT) help to create competitive advantage for a firm (Bhatt and Grover, 2005). The Hewlett-Packard microeconomy, called Netcard, is just one way in which the organization is using its intranet to manage knowledge. A Web-based directory, for example, offers a searchable, relational database featuring profiles of thousands of employees' expertise, interests, and geographic locations. And for the company's sales force, the Electronic Sales Partner offers a repository of product and customer information. (Greco, 1999).

The managerial decision for IT infrastructures is generally not whether to invest in IT, but rather how to obtain needed capabilities at lowest cost. When new levels of service to existing customers require that incremental power or features be added to the base structure, companies try to compare the net incremental costs and benefits of each feature, in financial terms if possible (Quinn and Bialy, 1994). Over the past eight years, the service sector has put nearly all of its incremental capital endowment into information technology. In fact, the service sector now owns more than $85 \%$ of America's installed base of information technology. Not surprisingly, the service sector has a far greater proportion of its total capital committed to information technology than manufacturing does. In 1982, services invested $\$ 6,000$ in information technology for each white-collar worker. Since then, the capital per white-collar worker has essentially doubled. (Roach, 199). But some researchers claim that there is no correlation between IT investment and organizational success. Many investigators still think that the benefits of IT are inadequate and they claim that expenses of IT do not attain their object in productivity (Weill, 1992; Strassman, 1990). On the other hand, some researchers claim that expenses paid for IT are beneficial for increased productivity (Brynjolfsson and Hitt, 1993; Osterman, 1986).

\section{H2: Information technology practices have a direct and positive effect on firm performance.}

Information technology lets people work together more closely. Traditional mainframe-oriented Information Processing was revolutionized in the 1980 's by the Personal Computer (PC). Today, PC's are commonplace and mostly part of Local Area Networks (LAN), or even Wide Area Networks (WAN), which electronically link teams, to allow nonphysical collaborative work. Special software systems, like E-mail, groupware, workflow-management, teleconferencing, etc. are elements of this pervasive role, Information Technology is taking (Schumacher, 1997). Information technology is fast becoming an integral part of management. Most management decisions cannot be implemented effectively without responsive information systems. Information systems are becoming a primary enabler of strategic or managerial changes. Without the appropriate support of IT, it would be virtually impossible to transform a traditional organization into a world-class organization (Lee and Kim, 1996).

\section{H3: Internal benefits of IT have a direct and positive effect on firm innovation.}

With IT it is generally possible to take advantage by increasing system productivity, providing higher quality goods and services, minimizing costs, developing new 
information-based products and raising competitive power. Also, a competitive advantage may be realized by an organization using IT in all management process as the inevitable path to success (Kazan et al., 2002).

\section{H4: Internal benefits of IT have direct and positive effect on firm performance.}

This finding suggests that heavy IT users paid greater attention to and spent more time on the roles they performed best with the technology (informationrelated activities) and may in fact have been embarking on an over-specialization trajectory (Pinsonneault and Suzanne, 1998). The role of it in shaping tomorrow's business operations is a distinctive one. It has become a fundamental enabler in creating and maintaining a flexible business network (Venkatnaman, 1994). They are all too aware that information technology is vital to strategic success (Dempsey et al., 1997).

\section{H5: The dynamic benefits of IT have a direct and positive effect on firm innovation.}

In the present day, when information is an instrument of power, developed countries and huge organizations contribute a large part of their investment in information and communication technologies (Göker, 1995). An information technology (IT) infrastructure is vitally important to companies, particularly those in industries going through dynamic change, those reengineering their business Processes, and those with widely dispersed operations. IT infrastructure investment are long-term commitments that account for more than 58 percent of the total IT budget of large firms and about 4 percent of revenues; they have increased at about 11 percent annually (Broadbent and Weil, 1997).

\section{H6: The dynamic benefits of IT have a direct and positive effect on firm performance.}

\section{Organizational Learning}

Learning comes into being with different mechanisms at a very wide range, and as a result, causes a change on behaviour (Ceylan, 1998). Some definitions which provide important contributions to individual learning processes are presented below; Corsini (1987) sees individual learning as involving five kinds of learned capabilities. Verbal knowledge (declarative knowledge) ranges from isolated 'facts' to bodies of organized information. Intellectual skills (procedural knowledge) enable the individual to demonstrate the application of concepts and rules to specific instances. Cognitive strategies involve a number of processes such as perceiving, encoding, retrieving and thinking; they can be problem-solving, and can control and modify other cognitive processes of learning and memory such as attention, encoding and retrieval. Attitudes are 'learned states that influence the choices of personal action the individual makes towards persons, objects or events'. Motor skills are smoothly timed muscular movements enabling procedures to be undertaken precisely (Dodgson, 1993). The dictionary definition states that learning is "the acquiring of knowledge or skill." Thus learning encompasses two meanings: (1) the acquisition of skill or know-how, which implies the physical ability to produce some action and (2) the acquisition of know-why, which implies the ability to articulate a conceptual understanding of an experience (Kim, 1993). Argyris and Schön (1996) are even less restricting in their definition declaring that organizational learning emerges when organizations acquire information (knowledge, understandings, know-how, techniques and procedures) of any kind by any means (Dimovski and Škerlavaj, 2005).

Concepts of organizational learning revealed in the mid 1970s, were primarily defined as "catching and correcting the mistakes". According to Huber (1991) Further, learning does not always increase the learner's effectiveness, or even potential effectiveness. Learning does not always lead to veridical knowledge. Sample data are not always representative and new findings sometimes overturn what was previously "known to be true." Entities can incorrectly learn, and they can correctly learn that which is incorrect. Finally, learning need not result in observable changes in behaviour. The traditional definition of learning as a shift in performance when the stimulus situation remains essentially the same implies a set of conditions that occur rarely in organizations. Thus, either organizational learning is an infrequent event, or it occurs frequently but takes a non-traditional form (Weick, 1991).

The concept of organizational learning with institutional application was first used in "The Fifth Discipline" published by Peter Senge in 1990. Senge emphasizes that the five disciplines must develop as an ensemble. Concerning e.g. system thinking Senge (1992) writes: "... system thinking [also] needs the disciplines of building shared vision, mental models, team learning, and personal mastery to realize its potential. Building shared vision fosters a commitment to the long term. Mental models focuses on the openness needed to unearth shortcomings in our present ways of seeing the world. Team learning develops the skills of groups of people to look for the larger picture that lies beyond individual perspectives. And personal mastery fosters the personal motivation to continually learn how our actions affect our world." (Senge, 1992).

Although the meaning of the term "learning" remains 
essentially the same as in the individual case, the learning process is fundamentally different at the organizational level. In the early stage of an organization's existence, organizational learning is often synonymous with individual learning because the organization consists of a small group of people and has minimal structure. As an organization grows, however, a distinction between individual and organizational learning emerges, and a system for capturing the learning of its individual members evolves (Kim, 1993). To be a learning organization, individual learning followed by organizational learning are necessary. Organizational learning is defined as "to transfer individual learning to the working space" (Dinçer, 1994).

Understanding what contributes to learning capacity, and what factors differentiate good organizational learners from poor organizational learners, is important because: 1) There is general agreement among learning theorists that organizational learning promises to contribute to understanding performance variations across organizations. 2) Performance variations, studies suggest, can generally be explained as differences in the rates at which organizations learn, the ease with which they innovate, and differences in the effectiveness of the processes and mechanisms by which new knowledge is applied to decision making in organizations (Berta et al., 2005).

\section{H7: Organizational Learning has a direct and positive effect on firm innovation.}

Organizational theorists have studied learning for a long time; the accompanying quotations suggest that there is still considerable disagreement. Most scholars view organizational learning as a process that unfolds over time and link it with knowledge acquisition and improved performance. (Garvin, David, 1993). In today's competitive climate, where the only certainty is uncertainty, organizational learning is considered a key factor of business success and is seen as the foundation of competitive advantage. In knowledgebased societies, knowledge has become the most important strategic asset. Organizations need to use knowledge to realize competitive advantages in the changing business environment (Sohal et al., 2004). We have to be aware of the fact that various aspects of organizational learning contribute to performance. Companies that will manage to develop organizational learning of higher level will gain in terms of higher profits and value added per employee relative to its competitors. Besides that, relationships with their main groups of stakeholders will improve. Besides improved financial picture of the company, higher level organizational learning endorses better relationships with employees, customers and suppliers (Dimovski and Škerlavaj, 2005).

\section{H8: Organizational Learning has a direct and positive effect on firm performance.}

\section{Firm Innovation}

Innovations vary in complexity and can range from minor changes to existing products, processes, or services to breakthrough products, and processes or services that introduce first-time features or exceptional performance. Process definition of innovation proponents concern themselves mainly with how the interplay between events and people at each stage of the process influences events in subsequent stages, determining whether the adoption process will continue (Cooper, 1998). Organizational innovation is defined as "engaging in and supporting new ideas, novelty, experimentation, and creative processes that may result in new products, services, or technological Processes" (Lumpkin and Dess, 1996).

Most significantly, organizations that adopt an innovation strategy in pursuit of developing new products and/or processes have the potential to outperform their competitors. In fact Hill and Jones (1998) state that innovation is perhaps the single most important building block of competitive advantage (Richard et al., 2003). For an organization to develop the capacity for sustained innovation as a meaningful component of strategy, it must make resources available for new products and provide collaborative structures and process to solve problems creatively and connect innovations with existing business (Bhaskaran, 2006). Tree types of impacts are measured in innovation studies: total factor productivity, which focuses on the differences in productive efficiency with the increase of the market power obtained through innovation (e.g., a product that is new for the market); and exports, which are related to knowledge-based comparative advantages. All these effects, along with public policies, help explain the funding of research expenditures. Innovation is associated with higher performance but the relationship between performances and innovation remains complex (Duguet, 2003).

These results are obtained when we evaluate innovation according to size of the organizations; in smaller organizations, top management is one person who is in sole charge of technological innovation. In large organizations, innovation is provided through buying patents and licenses. According to this, there are two sources of innovation; resources in the organization and resources external to the organization. Information Technologies, human resources and organizational factors are quite influential on innovation in the 
organization, and innovation has a significant role on stimulating the firm performance.

H9: Firm innovation has a direct and positive effect on firm performance.

\section{Firm Performance}

The simplest definition of performance is to measure productivity. Performance is generally stated as a doing business, implementing successfully. Performance, the main criteria of measuring success, could be defined as quite a wide concept that evaluates the ability to successfully achieve the organization's targets (Akal, 1994). It is necessary that the criteria chosen to measure performance are objective and clear. The performance measures that are analyzed correctly are one of the components that provide a big contribution to an organization's operations and success.

Evaluating organizational performance cannot be done without taking into consideration organizational goals (Dimovski and Škerlavaj, 2005). Firm performance is enhanced when there are synergies among the elements of system. Complementary factors of a system of mutually enhancing elements operate in such a way that doing more of one thing increases the return of doing more of another (Huang and Liu, 2005). Beside financial performance (FP) also nonfinancial performance (NFP) must be assessed in order to evaluate overall organizational performance of a modern company. There are two main reasons for such a requirement. First, several interest groups are involved in business and they all have their particular goals and expectations related to the company. They will remain in the coalition as long as their goals are satisfied in sufficient manner. Second, strategic business areas are not necessarily financial in their nature. Several approaches to non-financial indicators selection exist, of which the most established is Balanced Scorecard - BSC (Kaplan and Norton, 1993).

However, many classic measures still maintain validity to evaluate performance. In the present day, they are inefficient for conditions of specialization and competition. Reconstructing performance management systems do not only bring innovation to measuring the organization's performance, but may also be used to develop similar measures, evaluate and apply to the conditions that organization faces. Today's managers recognize the impact that measures have on performance. But they rarely think of measurement as an essential part of their strategy. For example, executives may introduce new strategies and innovative operating processes intended to achieve breakthrough performance, and then continue to use the same shortterm financial indicators they have used for decades, measures like returnon-investment, sales growth, and operating income. These managers fail not only to introduce new measures to monitor new goals and processes but also to question whether or not their old measures are relevant to the new initiatives (Kaplan and Norton, 1993).

For this reason, effective performance management systems that harmonize an organization's strategic objectives and targets should be constructed. Companies should establish performance measurement systems that support their strategies. Performance measurement systems should contain many nonfinancial indicators to complement financial ones, particularly with respect to customer perceptions and

\section{EXIHIBIT 1: RESEARCH MODEL}

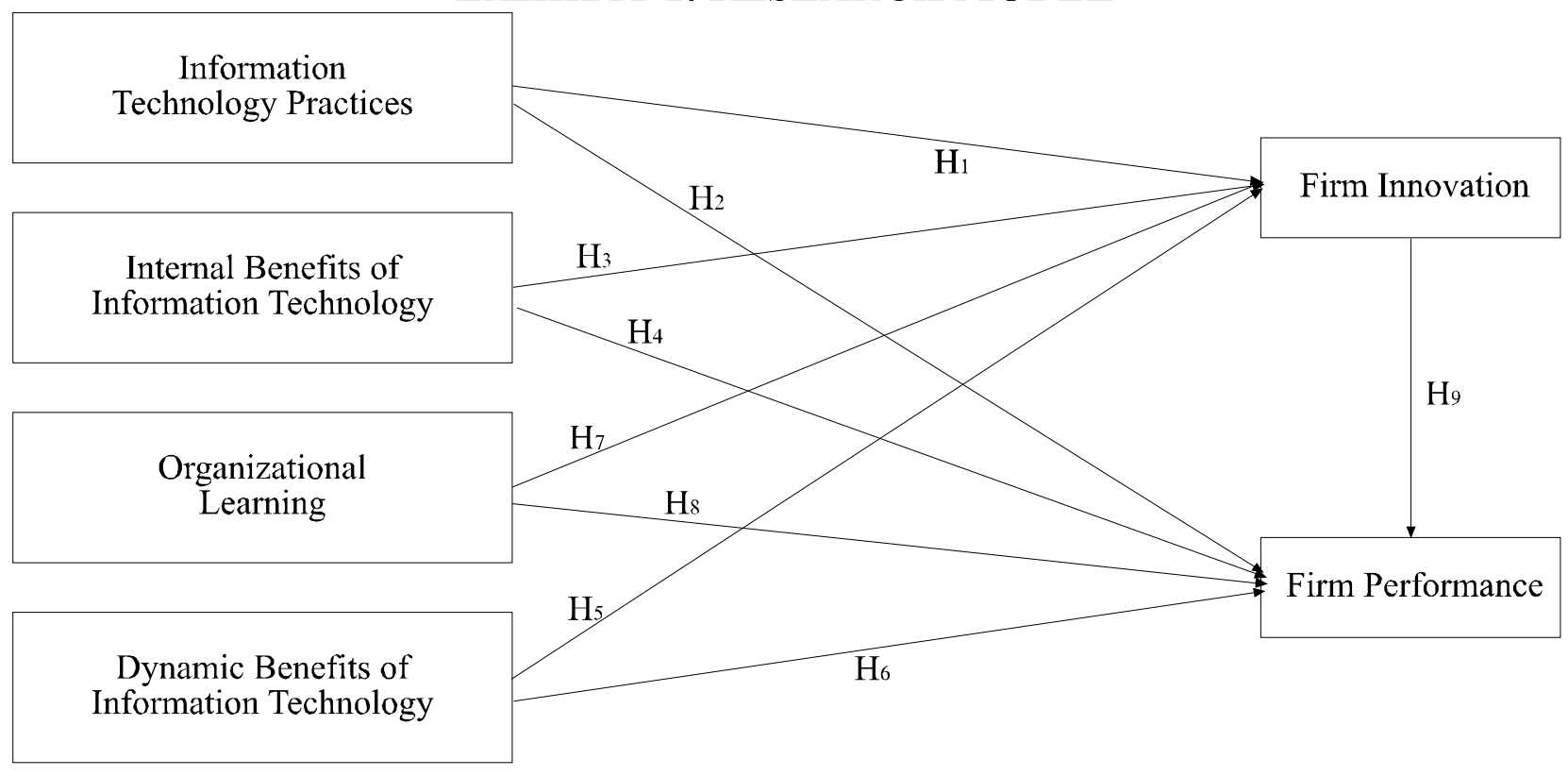


performance of internal processes. The company's overall performance measurement system should be broken down into sets of local measurements for lower-level units to translate (cascade) the firm's objectives into more manageable subsets (Epstein and Manzoni, 1997).

In our research, with the guidelines of literature review and previous empirical research, a research model has been developed to predict the effects of the IT practices, internal benefits of IT, organizational learning, dynamic benefits of IT, and firm innovation on firm performance. The research model is presented below:

\section{METHODOLOGY AND RESULTS}

\section{Sample and Data Collection}

In this study, we gathered data from a sample of 87 people who work in 18 different sectors in and around Istanbul. We gathered the questionnaires by meeting with the people face to face and we reached some accountants via the Internet Technology in accordance with our study. For this process we used the website that is designed in PHP program and data is saved in a MYSQL database. We tested the data with the help of regression analysis and all items included in the questionnaire were measured on a 5-point Likert-type scale. The items that we used were mostly tested in previous research and are proven to be theoretically strong.

\section{Measures}

In our study we have used the scale of 35 items to measure the variables. All the scales are empirically tested in previous research and they are generally accepted in the literature.

\section{Factor Analysis}

We used SPSS software, version 10.00 for the evaluation of our data. Factor analysis, correlation, reliability tests, the means of the variables and regression analysis are used to analyze the relationship between variables of the research model.

Since the scales that are used have been generally tested in previous research, they are theoretically strong. However, varimax rotational, exploratory factor analysis in SPSS software has been used to evaluate factor structure for the variables. The scales were submitted to principle component analysis with varimax rotation and six-factor solution was obtained as expected. We used the Cronbach's Alpha to estimate reliability for scales. These items and factor loadings are presented in Table 1.

Correlation analysis results have demonstrated that the independent relationships of all the variables in this study are significantly and positively correlated to each other. However, the effects of IT dynamic benefits, organizational learning, IT practices, IT internal benefits, firm innovation on business performance were our research questions. Thus, we have also conducted multiple regression analysis to investigate our hypothesis.

\section{Correlations and Associations between Variables of the Study}

Correlation analysis is conducted to research the relationship between IT dynamic benefits, organizational learning, IT practices, IT internal benefits, firm innovation and firm performance. As seen in Table 2, a positive and strong correlation is attracted attention at a significant level of $p<0,01$ between the variables. As can be seen from the correlation table (Table 2) below, all dimensions are correlated.

Correlation analysis results have demonstrated that the independent relationships of all the variables in this study are significantly and positively correlated to each other. However, the effects of IT dynamic benefits, organizational learning, IT practices, IT internal benefits, firm innovation on business performance were our research questions. Thus, we have also conducted multiple regression analysis to investigate our hypothesis.

\section{Test of the Hypotheses}

Firstly, to understand if IT dynamic benefits, organizational learning, IT practices, IT internal benefits have an impact on firm innovation. According to this analysis (Table 3); H1, H3, H5, $\mathrm{H} 7$ hypotheses are statistically significant. When IT dynamic benefits, organizational learning, IT practices, IT internal benefits are investigated separately, it is shown that all these variables have a positive effect on the firm innovation. 
TABLE 1: FACTOR LOADINGS OF RESEARCH DIMENSIONS

\begin{tabular}{|c|c|c|c|c|c|c|}
\hline Factors and Scales & $\begin{array}{r}\text { Factor } \\
1\end{array}$ & $\begin{array}{r}\text { Factor } \\
\mathbf{2}\end{array}$ & $\begin{array}{r}\text { Factor } \\
\mathbf{3}\end{array}$ & $\begin{array}{r}\text { Factor } \\
4\end{array}$ & $\begin{array}{r}\text { Factor } \\
\mathbf{5}\end{array}$ & $\begin{array}{r}\text { Factor } \\
\mathbf{6} \\
\end{array}$ \\
\hline \multicolumn{7}{|l|}{ 1. Dynamic Benefits of IT (Crombach $\alpha$ : 0,9359) } \\
\hline Customer relationship gets better through IT. & 0.809 & & & & & \\
\hline $\begin{array}{l}\text { Our IT System is beneficial to improve } \\
\text { communication and solidarity among the } \\
\text { organization's departments. }\end{array}$ & 0.799 & & & & & \\
\hline \multicolumn{7}{|l|}{ Our IT System is beneficial to improve our } \\
\hline $\begin{array}{l}\text { external relationship with components such as } \\
\text { our supplier, customer and supply chain members. }\end{array}$ & 0.799 & & & & & \\
\hline $\begin{array}{l}\text { Our IT System is beneficial to improve our } \\
\text { internal relationship that is implemented among } \\
\text { the different departments and hierarchical levels. }\end{array}$ & 0.793 & & & & & \\
\hline Thanks to IT, mutual trust with sellers is enhanced. & 0.780 & & & & & \\
\hline $\begin{array}{l}\text { Our IT system helps us to new products and } \\
\text { service development projects. }\end{array}$ & 0.744 & & & & & \\
\hline $\begin{array}{l}\text { Our IT system helps us to improve our } \\
\text { technological information. }\end{array}$ & 0.716 & & & & & \\
\hline $\begin{array}{l}\text { Thanks to IT system the effectiveness } \\
\text { of resource management is improved. }\end{array}$ & 0.707 & & & & & \\
\hline $\begin{array}{l}\text { Thanks to IT, contribution is provided to } \\
\text { not duplicating strategic value. }\end{array}$ & 0.629 & & & & & \\
\hline \multicolumn{7}{|l|}{ 2. Organizational Learning (Crombach $\alpha$ : 0,9126) } \\
\hline $\begin{array}{l}\text { Learning is seen as a key value that is necessary } \\
\text { to ensure the continuation of an } \\
\text { organization's presence. }\end{array}$ & & 0.808 & & & & \\
\hline $\begin{array}{l}\text { Learning of employees is not evaluated as } \\
\text { a cost; it is evaluated as an investment. }\end{array}$ & & 0.799 & & & & \\
\hline There is purpose togetherness in organization. & & 0,778 & & & & \\
\hline $\begin{array}{l}\text { Employees see themselves like partners } \\
\text { of the organization in planning its direction. }\end{array}$ & & 0.766 & & & & \\
\hline $\begin{array}{l}\text { All employees commit to the } \\
\text { organization's targets. }\end{array}$ & & 0.738 & & & & \\
\hline \multicolumn{7}{|l|}{ There is a collective consensus of opinion } \\
\hline $\begin{array}{l}\text { relating to organizational vision at all } \\
\text { levels, function and departments. }\end{array}$ & & 0.708 & & & & \\
\hline $\begin{array}{l}\text { The basic values of this organization } \\
\text { cover learning as a key of development. }\end{array}$ & & 0.673 & & & & \\
\hline $\begin{array}{l}\text { We don't abstain to think critically on } \\
\text { common predictions related to our customer. }\end{array}$ & & 0.645 & & & & \\
\hline \multicolumn{7}{|l|}{ 3. Firm Performance (Crombach $\alpha: \mathbf{0 , 8 8 6 6 )}$} \\
\hline $\begin{array}{l}\text { Waste products and cost of reprocessing } \\
\text { is decreasing as a percentage of sales. }\end{array}$ & & & 0.827 & & & \\
\hline $\begin{array}{l}\text { The delivery time of material } \\
\text { purchases is shortening. }\end{array}$ & & & 0.793 & & & \\
\hline Customer complaints are decreasing. & & & 0.725 & & & \\
\hline $\begin{array}{l}\text { Product/Services quality corresponds } \\
\text { or exceeds the demands of customer. }\end{array}$ & & & 0.689 & & & \\
\hline The level of customer satisfaction is increasing. & & & 0.687 & & & \\
\hline $\begin{array}{l}\text { The delivery time of uncompleted } \\
\text { products and services is decreasing. }\end{array}$ & & & 0.679 & & & \\
\hline
\end{tabular}




\begin{tabular}{|c|c|c|c|}
\hline 4. IT Practices (Crombach $\alpha: 0,8578)$ & & & \\
\hline $\begin{array}{l}\text { In our organization, institutional portal } \\
\text { practices are used. }\end{array}$ & 0.724 & & \\
\hline $\begin{array}{l}\text { In our organization, teleconference } \\
\text { systems are used. }\end{array}$ & 0.723 & & \\
\hline $\begin{array}{l}\text { Our organization benefits from out sourcing } \\
\text { and consulting service in IT. }\end{array}$ & 0.722 & & \\
\hline $\begin{array}{l}\text { The main works in our organization are } \\
\text { done on the online workflow systems. }\end{array}$ & 0.720 & & \\
\hline $\begin{array}{l}\text { In our organization, supply chain } \\
\text { management systems are used effectively. }\end{array}$ & 0.694 & & \\
\hline $\begin{array}{l}\text { In our organization, customer relation } \\
\text { management systems are used. }\end{array}$ & 0.594 & & \\
\hline 5. Firm Innovation (Crombach $\alpha: 0,8491$ ) & & & \\
\hline $\begin{array}{l}\text { Our organization research ideas of new } \\
\text { technologies, processes, techniques and } \\
\text { products/services. }\end{array}$ & & 0.691 & \\
\hline $\begin{array}{l}\text { Technical innovations that are based on } \\
\text { research results find acceptance very quickly. }\end{array}$ & & 0.686 & \\
\hline $\begin{array}{l}\text { In our organization, innovative ideas and } \\
\text { practices are perceived as quite risky } \\
\text { and received with resistance. }\end{array}$ & & 0.625 & \\
\hline $\begin{array}{l}\text { In our organization, to practice new ideas, } \\
\text { appropriate plans and programs are composed. }\end{array}$ & & 0.592 & \\
\hline 6. Internal Benefits of IT (Crombach $\alpha: \mathbf{0 , 8 0 8 3}$ & & & \\
\hline IT reduces uncertainty of information loss. & & & 0.789 \\
\hline $\begin{array}{l}\text { IT is used comprehensively by the } \\
\text { members of organization. }\end{array}$ & & & 0.732 \\
\hline
\end{tabular}

TABLE 2: MEAN, STANDARD DEVIATION and CORRELATION COEFFICIENTS

\begin{tabular}{|c|c|c|c|c|c|c|c|c|}
\hline VARIABLES & $\stackrel{\stackrel{\Xi}{E}}{\sum_{\Sigma}^{\oplus}}$ & 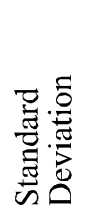 & 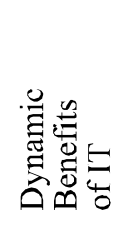 & 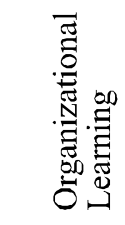 & 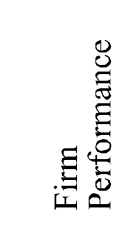 & 巨总 & 莺总 & 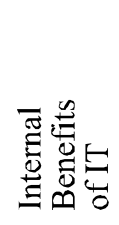 \\
\hline Dynamic Benefits of IT & 3,74 & 1,02 & 1 & & & & & \\
\hline Organizational Learning & 3,48 & ,93 &, $360 * *$ & 1 & & & & \\
\hline Firm Performance & 3,30 & 1,04 &, $435^{* *}$ &, $347 * *$ & 1 & & & \\
\hline IT Practices & 3,33 & 1,10 &, $575^{* *}$ &, $286^{* *}$ &, $410^{* *}$ & 1 & & \\
\hline Firm Innovation & 3,47 & ,97 &, $402 * *$ &, $670^{* *}$ &, $496 * *$ &, $345^{* *}$ & 1 & \\
\hline Internal Benefits of IT & 3,89 & 1,03 &, $524^{* *}$ &, $423 * *$ &, $410 * *$ &, $405^{* *}$ &, $429 * *$ & 1 \\
\hline
\end{tabular}

$* *$ Pearson Correlation, It is significant at $\mathrm{p}<0.01$ level 
TABLE 3: $1^{\text {st }}$ REGRESSION ANALYSIS RESULTS

\begin{tabular}{|l|c|c|c|r|}
\hline 1. Regression & \multicolumn{3}{|c|}{ Dependent Variable (Firm Innovation) } \\
Independent Variables & $\beta$ & Sig & $\mathrm{R}^{2}$ & $\mathrm{~F}$ \\
Dynamic Benefits of IT &, $402^{* *}$ &, 000 &, 152 & 16,414 \\
\hline Organizational Learning &, $670^{* *}$ &, 000 &, 442 & 69,251 \\
\hline IT Practices &, $345^{* *}$ &, 001 &, 109 & 11,503 \\
Internal Benefits of IT &, $429^{* *}$ &, 000 &, 174 & 19,141 \\
\hline
\end{tabular}

** Pearson Correlation, It is significant at $\mathrm{p}<0.01$ level

\section{EXIHIBIT 2: 1. REGRESSION MODEL}

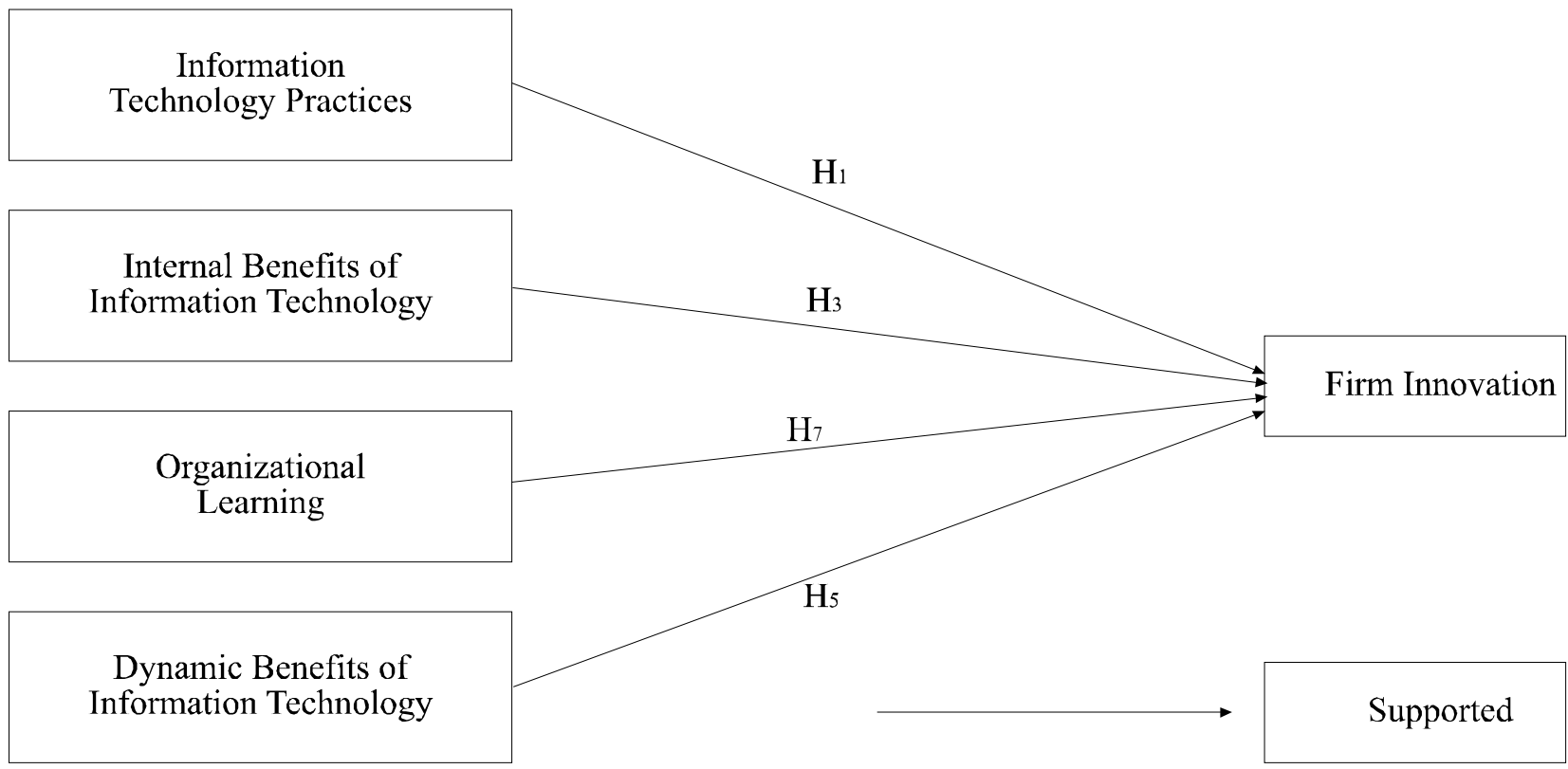

First, we made regression analyses between every variable with the firm performance separately. According to these regression analyses, it is found

that $\mathrm{H} 2, \mathrm{H} 4, \mathrm{H} 6, \mathrm{H} 8, \mathrm{H} 9$ hypotheses are statistically significant at the $\mathrm{p}<0.01$ significance level and all the variables have a positive impact on firm performance.

TABLE 4: $2^{\text {nd }}$ REGRESSION ANALYSIS RESULTS

\begin{tabular}{|l|l|r|r|r|}
\hline 2. Regression & \multicolumn{4}{|c|}{ Dependent Variable (Firm Performance) } \\
\hline Independent Variables & $\beta$ & Sig & R2 & F \\
\hline Dynamic Benefits of IT &, $435^{* *}$ &, 000 &, 180 & 19,821 \\
\hline Organizational Learning &, $347^{* *}$ &, 001 &, 110 & 11,663 \\
\hline IT Practices &, $410^{* *}$ &, 000 &, 159 & 17,215 \\
\hline Firm Innovation &, $496^{* *}$ &, 000 &, 237 & 27,680 \\
\hline Internal Benefits of IT &, $410^{* *}$ &, 000 &, 158 & 17,152 \\
\hline
\end{tabular}

** Pearson Correlation, It is significant at $\mathrm{p}<0.01$ level 


\section{EXIHIBIT 3: $2^{\text {nd }}$ REGRESSION MODEL}

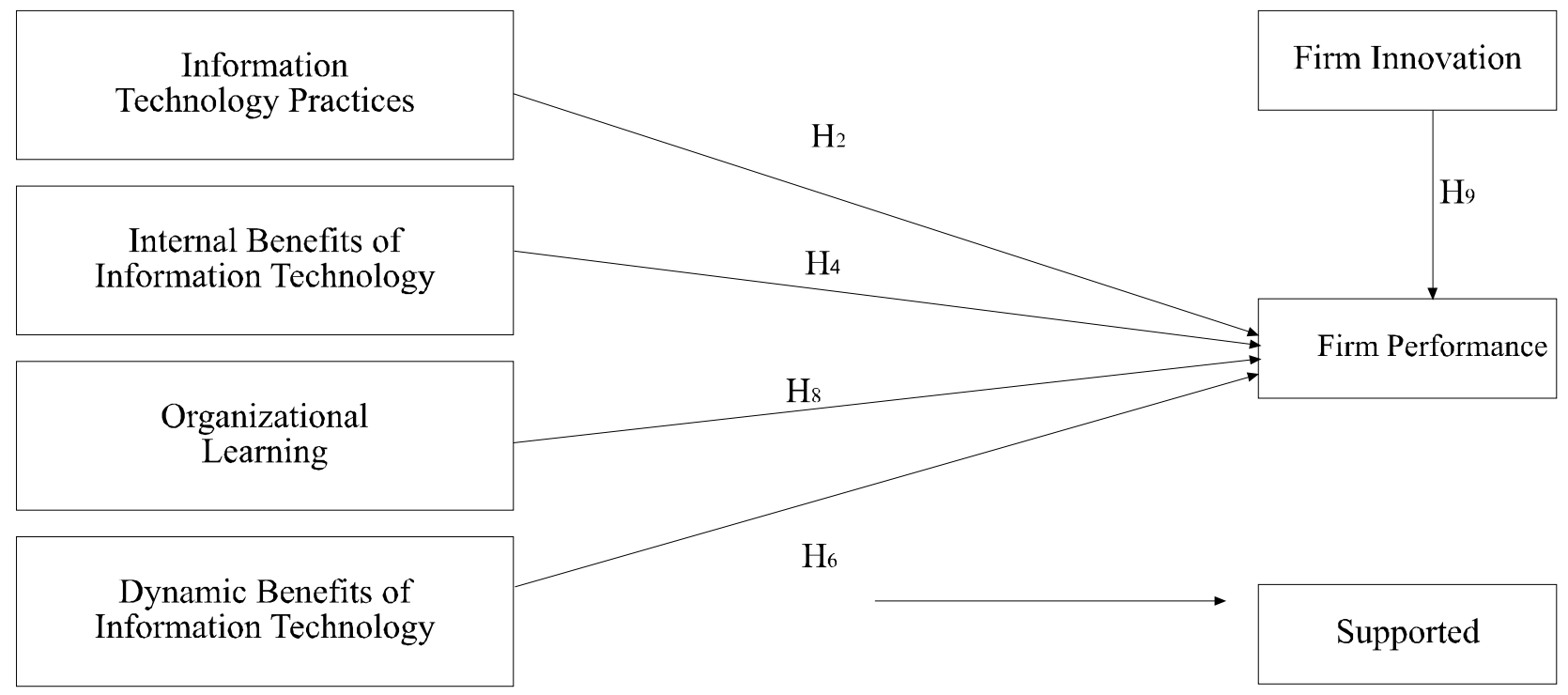

After the second regression analysis, we would like to learn what kind of relationship will be between the firm performance and other variables if they are all analysed one-to-one. So, we have also conducted multiple regression analyses to investigate our hypotheses.

For the multiple regression analysis that is made via SPSS 10.0 for Windows Statistical Analysis Program, firm performance is selected as a dependent variable and all the other variables selected as independent variables. The results of the analysis are shown in Table 5. When we look at the result of the analysis, we saw that only firm innovation (at the significance level of $p<0.05$ ) has a statistically significant effect on the firm performance and other variables do not have a statistically significant effect on firm performance.

\section{EXIHIBIT 4: $3^{\text {th }}$ REGRESSION MODEL}

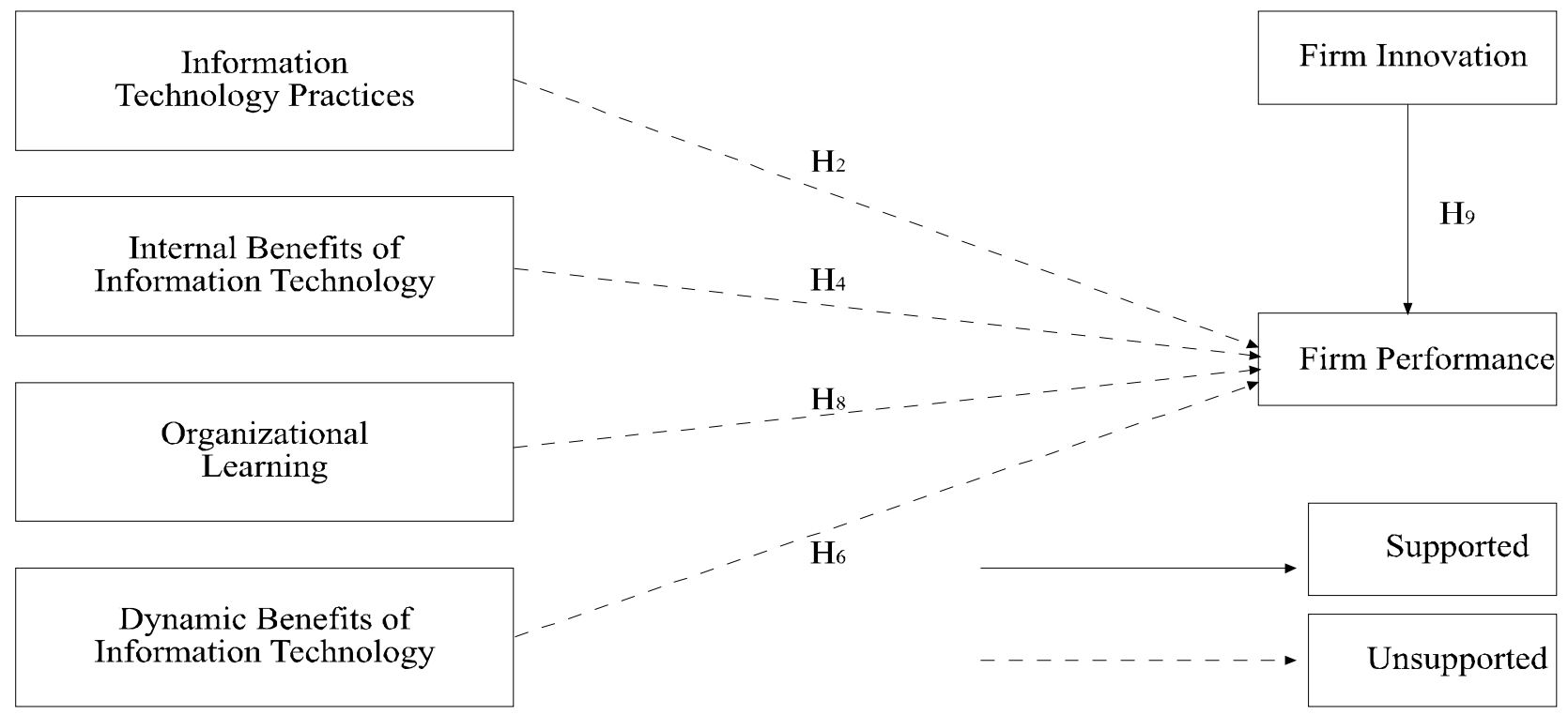


According to third regression analysis; $\mathrm{H} 2, \mathrm{H} 4, \mathrm{H} 6$, $\mathrm{H} 8$ hypotheses are not supported but at the second regression analysis (Table 4) these hypotheses are supported at $\mathrm{p}<0.01$ significance level. In the present case, we could say that variables overshadow each other and we learned that firm innovation has a moderating effect between other variables and firm performance. Firm innovation is a moderating variable between the other variables and firm performance. So we could reformulate our research model according to the regression analyses like below.

\section{EXIHIBIT 5: The RESULTS of the ANALYSES}

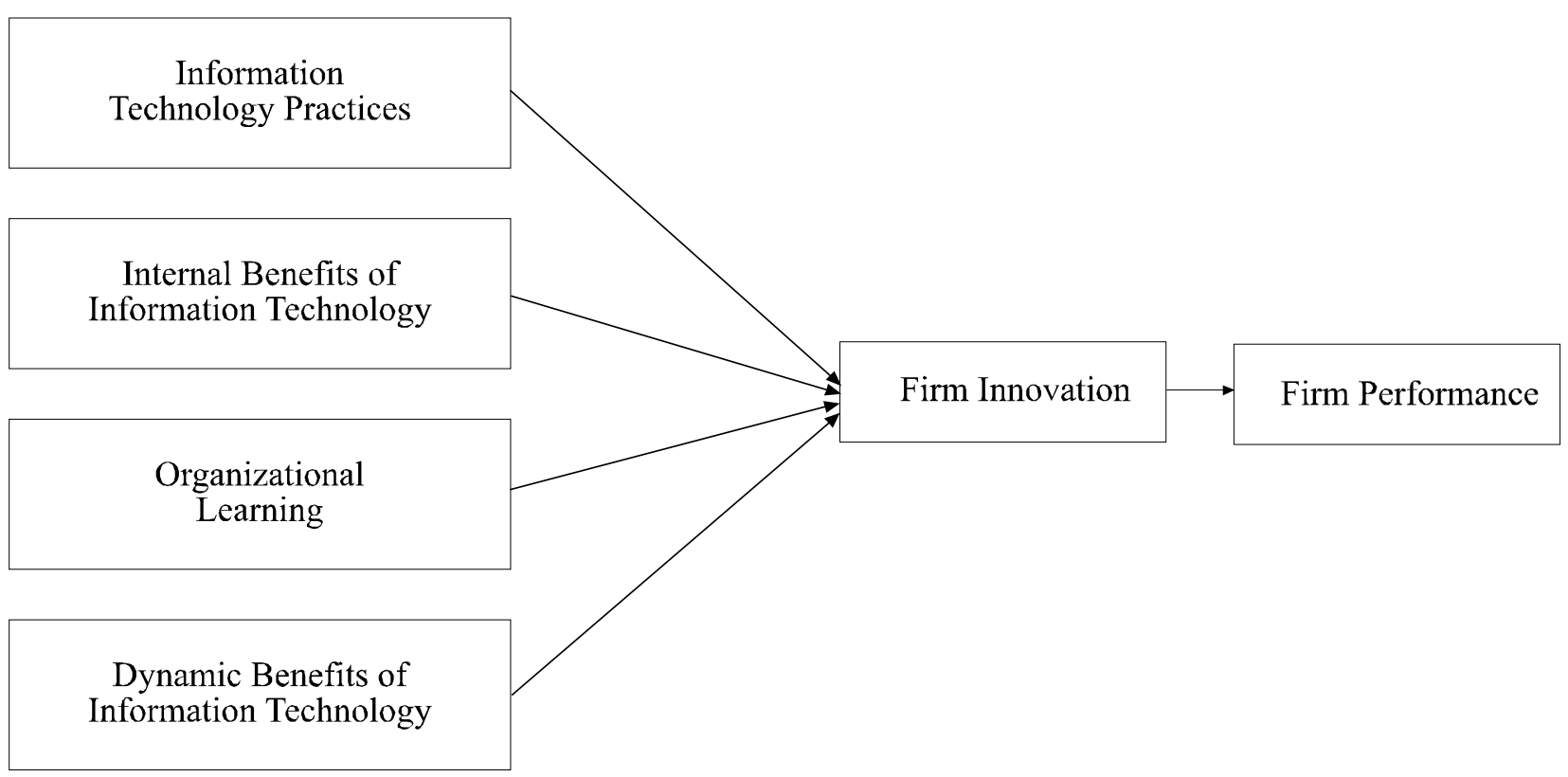

\section{DISCUSSION and CONCLUSION}

The findings of this study extend the IT, organizational learning, innovation and firm performance literature. And it builds a foundation for further understanding the link between innovation and IT and performance outcomes. First, the impact of innovation (both product and process) on performance (both profitability and growth) is primarily indirect and is instead fuelled by IT (Dibrell et al., 2008). No industry, no firm can hope to be at the top forever - unless it keeps innovating. Therefore, reducing costs may not be a reliable universal key any more; at the very least, this strategy should be employed concurrently with innovation when trying to improve competitiveness. Instead of strategies aiming at cost reductions, we should focus on innovation in our business strategy. Organizational learning is one of the processes of innovation within a firm, and as such, should be further studied (Yang et al., 2007). In this study, first of all, variables that are used for analysis are explained. After this step, hypotheses are developed and a research model is formed to test relationships between variables. Finally, using the data collected from a sample of 87 people who work in Turkish firms from 18 different sectors, we examined the potential effects of IT practices, internal benefits of IT, organizational learning, dynamic benefits of IT, and firm innovation on business performance via one-to-one regression analyses and multiple regression analysis.

The results of regression analysis have shown that all the variables (IT practices, internal benefits of IT, organizational learning, dynamic benefits of IT, and firm innovation) have a statistically significant and positive effect separately, but if we use multiple regression analyses, it is shown that IT practices, internal benefits of IT, organizational learning, dynamic benefits of IT have significant effects on firm performance by firm innovation, even though this effect is not direct. Only firm innovation has statistically significant and direct effect on firm performance. However, the correlation analysis results among all variables correlate with each other. All of the one-toone relations between all variables and firm performance have significant and positive correlations with each other.

The fact that IT practices, internal benefits of IT, organizational learning, dynamic benefits of IT, and firm innovation have effects on firm performance is supported by the results of research. In the light of these results, the companies that have willingness to grow should concentrate on information technology, organizational learning and firm innovation that provide high firm performance. 
Another important point is that information technology and organizational learning lead to firm innovation. By this logic we could say that information technology and organizational learning are part of firm innovation. Today we should not disregard rapid changes in information technology, and all departments in the firm are effected by these changes. To reach sufficient financial results, and efficient performance, firms should implement these changes as quickly as possible.

According to the results of our analysis, the impact of IT practices, internal benefits of IT, organizational learning, dynamic benefits of IT, and firm innovation on firm performance, it may be inferred that firm innovation has positive and significant effects on firm performance directly. Also firm innovation has a moderating effect between IT practices, internal benefits of IT, organizational learning, dynamic benefits of IT and firm performance. Therefore, IT practices, internal benefits of IT, organizational learning and dynamic benefits of IT are effective on firm performance by firm innovation and all these variables have a statistically significant and positive effect on firm innovation.

These results show that IT practices, internal benefits of IT, organizational learning, dynamic benefits of IT and firm innovation are vital components of firm performance. If it is taught that firms have to achieve a positive financial performance and every kind of firm performance in the recent competitive business environment; Firms have to give importance to IT practices, internal benefits of IT, organizational learning, dynamic benefits of IT, and firm innovation.

In further research, these variables may be applied to different sized firms and industries to research firm performance. Another important point for future research, competitive strategies could include the analysis. Thanks to this research, firms may develop new competitive strategies and gain an advantage against their rivals.

\section{REFERENCES}

Akal, Z. (1992). İsletmelerde Performans Olcum ve Denetimi (Cok Yonlu Performans Gostergeleri), Ankara: MPM Yayınları No: 473

Akal, Z. (1994). "İmalatçı Kamu ve Özel Kesim Kuruluşlarında İsletmeler arası Toplam Performans, Verimlilik, Karlılık ve Maliyet Karşılaştırmaları", MPM 555.

Applegate, L. M. (1998). "In Search of a New Organizational Model: Lessons from the Field", Communication Technology and Organizational Forms, DeSanctis and Fulk (eds.), Sage Publisations, Berkeley, CA.

Argyris, C., (1993). On Organizational Learning, Blackwell Publishers Inc.

Berta, W., Teare G. F., Gilbart E., Ginsburg, L. S., Lemieux-Charles, L., Davis D., Rappolt, S. (2005), "The Gontingencies of Organizational Learning in Long-Term Gare: Factors That Affect Innovation Adoption", Heakh Care Manage Rev, 2005, 10(4), 282-292

Bhaskaran, S. (2006), "Incremental Innovation and Business Performance: Small and Medium-Size Food Enterprises in a Concentrated Industry Environment", Journal of Small Business Menagement, 44(1), 6480.

Bhatt G. D., Grover V., (2005), "Types of Information Technology Capabilities and Their Role in Competitive Advantage: An Empirical Study", Joumal of Management Information Systems/Pa" 2005. Vol. 22. No. 2., 253-277.

Broadbent Marianne,Weill Peter,"Management by Maxim:How Business and IT Managers Can Create IT Infrastructures",Sloan Management Review,Spring 1997

Brynjolfsson, E. and Hitt, L. (1993). "Is Information Systems Spending Productive? New Evidence and New Results," In Proceedings of the Fourteenth International Conference on Information Systems, Oriando, FL, ss.47-64.

Ceylan A., (1998). Endüstri Örgütlerinde Davranış Değiştirme, Gebze, GYTE Yayın: 3.

Cooper, J. (1998). "A Multidimensional Approach to the Adoption of Innovation," Management Decision 36(8), 493-502.

Corsini, R., (1987). Concise encyclopedia of psychology. New York: Wiley.

Dempsey, J., Dvorak, R.E., Holen, E., Mark, D., 
Meehan, W.F., (1997). "Escaping the IT Abyss", The McKinsey Quarterly, 4.

Dimovski, V., Škerlavaj, M., (2005). "Performance Effects of Organizational Learning in a Transitional Economy", Problems and Perspectives in Management, 4.

Dibrell C., Davis, P. S., Craig, J., (2008). "Fueling Innovation through Information Technology in SMEs", Journal of Small Business Management, 46, 2

Dodgson, M. (1993). Organizational learning: a review of some literatures, Organization Studies.

Duguet, E., (2003). "Innovation and Firm Performance: Econometric Explorations of Survey Data", Journal of Economic Literature, 41/4.

Epstein, M. and Manzoni, J., (1997). "The Balanced Scorecard and tableau de bord: Translating Strategy into. Action", Management Accounting, (79:2), 2836.

Garvin, David A., (1993). "Building a learning organization", Harvard Business Review, Vol.71, Nr.4: 78-91.

Gaski, J.F. (1984), "The Theory of Power and Conflict in Channels of Distribution," Journal of Marketing, 48, pp. 9-29.

Göker M. A., (1995). "Bilim Teknolojisi Sanayi Üçlemesi", Sarmal Yayınevi, İstanbul, 150-151.

Greco, J., (1999). " Knowledge is Power ", Journal of Business Strategy.

Hatipoğlu, Z. (1993). "Temel Yönetim ve Organizasyon", Yeni İktisat ve İşletme Dizisi, No:12, Beta Yayınları, İstanbul.

Huang, C. J., and C. J. Liu (2005), "Exploration for the Relationship between Innovation, IT, and Performance," Journal of Intellectual Capital 6(2), 237-252.

Huber, 1991 G. Huber, Organizational learning: the contributing processes and the literatures, Organization Science 2 (1991), 88-115.

Kaplan, R. S. and Norton, D. P., (1993). "Putting the Balanced Scorecard to Work." Harvard Business Review, 134-142.

Kazan, H., Karadal H., ve Uygun, M., (2002). "Bilişim Teknolojilerine Geçiş Sürecinde Küçük Ve Orta Ölçekli Sanayi İşletmelerinin Temel Sorunlar: Aksaray Örneği", Doğu Akdeniz Üniversitesi İșletme Ve Ekonomi Fakültesi İşletme Bölümü' 21. Yüzyılda KOBİler: Sorunlar, Firsatlar Ve Çözüm Önerileri', Uluslar Arası Sempozyumu.
Kim, D. H., (1993). "The link between individual and organizational learning", Sloan Management Review, 35(1): 37-50.

Kim, W. C. and Mauborgne, R., (1997) "Fair Process: Managing in the Knowledge Economy", Harvard Business Review.

Koçel, T., (1989). "İşletme Yöneticiliği, Yönetici Geliştirme Organizasyon ve Davranış", Üçüncü Baskı, İstanbul İ. Fak. Yayınları, No: 101, İstanbul.

Lee, S., M, Kim B., (1996). "Developing the Information Systems Architecture for World-Class Organizations", Management Decision, 34-2.

Lumpkin G., Dess, G. (1996). "Clarifying the entrepreneurial orientation construct and linking it to performance", Academy of Menagement Review, 21, 135-172.

Luthans, Fred (1995). Organizational Behavior (Seventh Edition), McGraw Hill.

Osterman, P. (1986). "The Impact of Computers on the Employment of Clerks and Managers," Industrial and Labor Relations Review (39), 175-186.

Quinn, J. B. and Baily, N. (1994). "Information Technology: Increasing Productivity in Services," Academy of Management Executive (8:3), 28-47.

Ömer Dinçer," Örgüt Geliştirme Teori, Uygulama ve Teknikleri", Marmara Üniversitesi, 1992.

Özgener Şevki, (2003), "Global Ölçekte Değer Yaratan Bilgi Yönetimi Stratejileri", 2. Ulusal Bilgi, Ekonomi ve Yönetim Kongresi, Kocaeli,

http://www.ceterisparibus.net/kongre/kocaeli_2.htm.

Pinsonneault, A and Suzanne, R. (1998). "Information Technology and the Nature of Managerial Work: From the Productivity to the Icarus Paradox?" MIS Quarterly, September 1998, 287-311.

Richard, O., McMillan, A., Chadwick K., Dwyer S., (2003). "Employing an innovation strategy in racially diverse workforces: Effects on Firm Performance", Group \& Organization Management, 28, 1

Roach, S., (1991). "Service under siege-the restructuring imperative", Harvard Bus. Rev., 82-92.

Schumacher, Wolf D. "Managing Barriers to Business Reengineering Success", 07/10/2003, $\mathrm{http}: / /$ www.prosci.com/w_2.htm.

Senge, P., M., (1993). "The Fifth Discipline. The Art and Practice of the Learning Organization". New York.

Senge, P. M., (1990). "The Leader's New Work:

Building Learning Organizations", Sloan Management Review. 
Senge, P. M. (1992). The Fifth Discipline - The Art \& Practice of the Learning Organization. (1st ed. 1990, New York, NY: Currency/Doubleday). London: Century Business.

Sohal, A. S., Chung, W.W. C. \& Morrison, M. (2004) "In search of learning organisations: case experiences from Hong Kong", International Journal of Technology Management, 2(6/7), 656-673.

Strassman, P. (1990). "The Business Value of Computers, Connecticut", Information Economics Press, New Canaan.

Teece, D.J., G. Pisano and A. Shuen (1997). "Dynamic capabilities and strategic management", Strategic Management Journal, Vo.18 (7), 509-533

Venkatraman, N. (1994). "IT-Enabled Business Transformation: From Automation to Business Scope Redefinition", Sloan Management Review, Vol. 36, 73-87.

Weick, K., (1991). "The nontraditional quality of organizational learning", Organization Science 2, 116124.

Weill, P. (1992). "The Relationship Between Investment and Information Technology and Firm Performance: A Study of the Valve Manufecturing Sector," Information Systems Research, (3:4), 307333.

Yang, C., Wang, Y., Niu, H., (2007). "Does Industry Matter in Attributing Organizational Learning to its Performance?: Evidence from the Taiwanese Economy", Asia Pacific Business Review Vol. 13, No. 4, 547-563. 